\title{
Road Transport and Power System Scenarios for Northern Europe in 2030
}

\author{
Juul, Nina; Meibom, Peter
}

Publication date:

2011

Document Version

Publisher's PDF, also known as Version of record

Link back to DTU Orbit

Citation (APA):

Juul, N. (Author), \& Meibom, P. (Author). (2011). Road Transport and Power System Scenarios for Northern Europe in 2030. Sound/Visual production (digital)

\section{General rights}

Copyright and moral rights for the publications made accessible in the public portal are retained by the authors and/or other copyright owners and it is a condition of accessing publications that users recognise and abide by the legal requirements associated with these rights.

- Users may download and print one copy of any publication from the public portal for the purpose of private study or research.

- You may not further distribute the material or use it for any profit-making activity or commercial gain

- You may freely distribute the URL identifying the publication in the public portal

If you believe that this document breaches copyright please contact us providing details, and we will remove access to the work immediately and investigate your claim 


\section{Road Transport and Power System Scenarios for Northern Europe in 2030}

Nina Juul \& Peter Meibom, Risø DTU

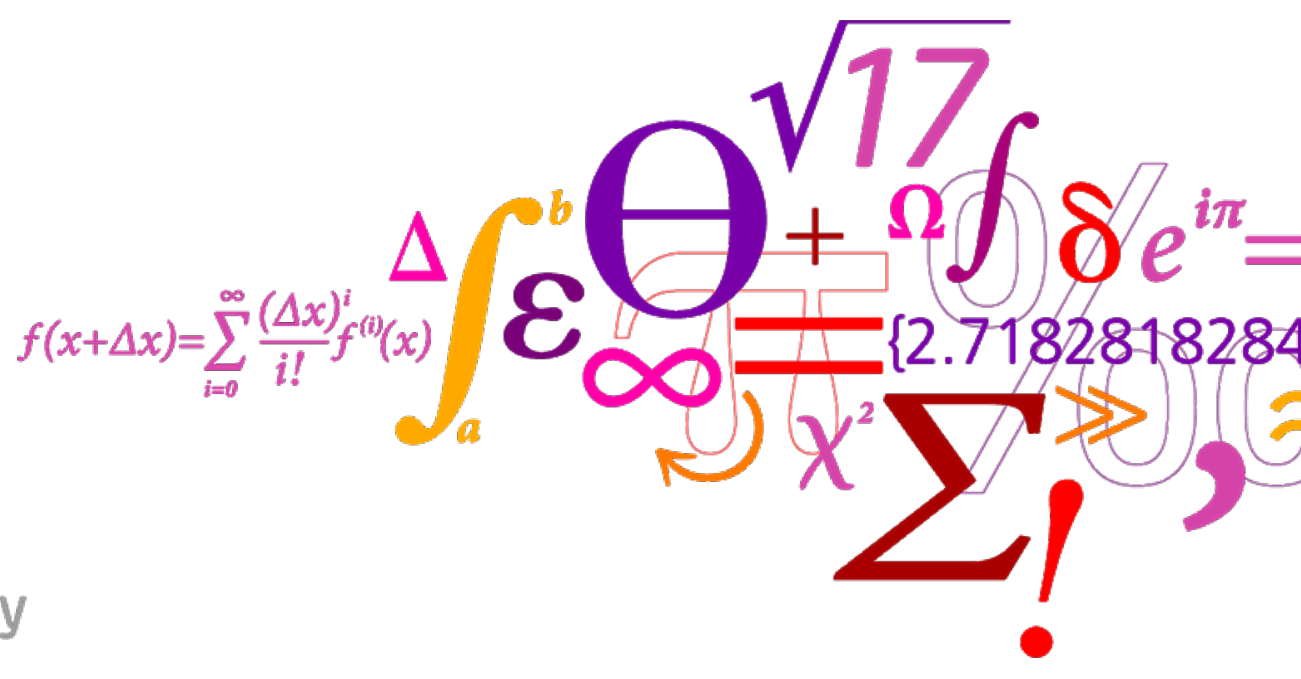




\section{Purpose}

- Adding transport to a power system model (Balmorel) enables analysis of:

- consequences of possibility of using electric power in transport sector

- consequences of adding vehicle-to-grid technologies

- competition between different vehicle technologies 


\section{Balmorel (www.balmorel.com)}

- Investment model: calculates optimal future configurations of power systems

- Power plants, CHP plants, boilers, heat pumps, electricity and heat storages, transmission lines

- Lately:

- hydrogen storage, production (electrolysis, steam reforming), consumption 


\section{Sketch of the Balmorel model including transport}

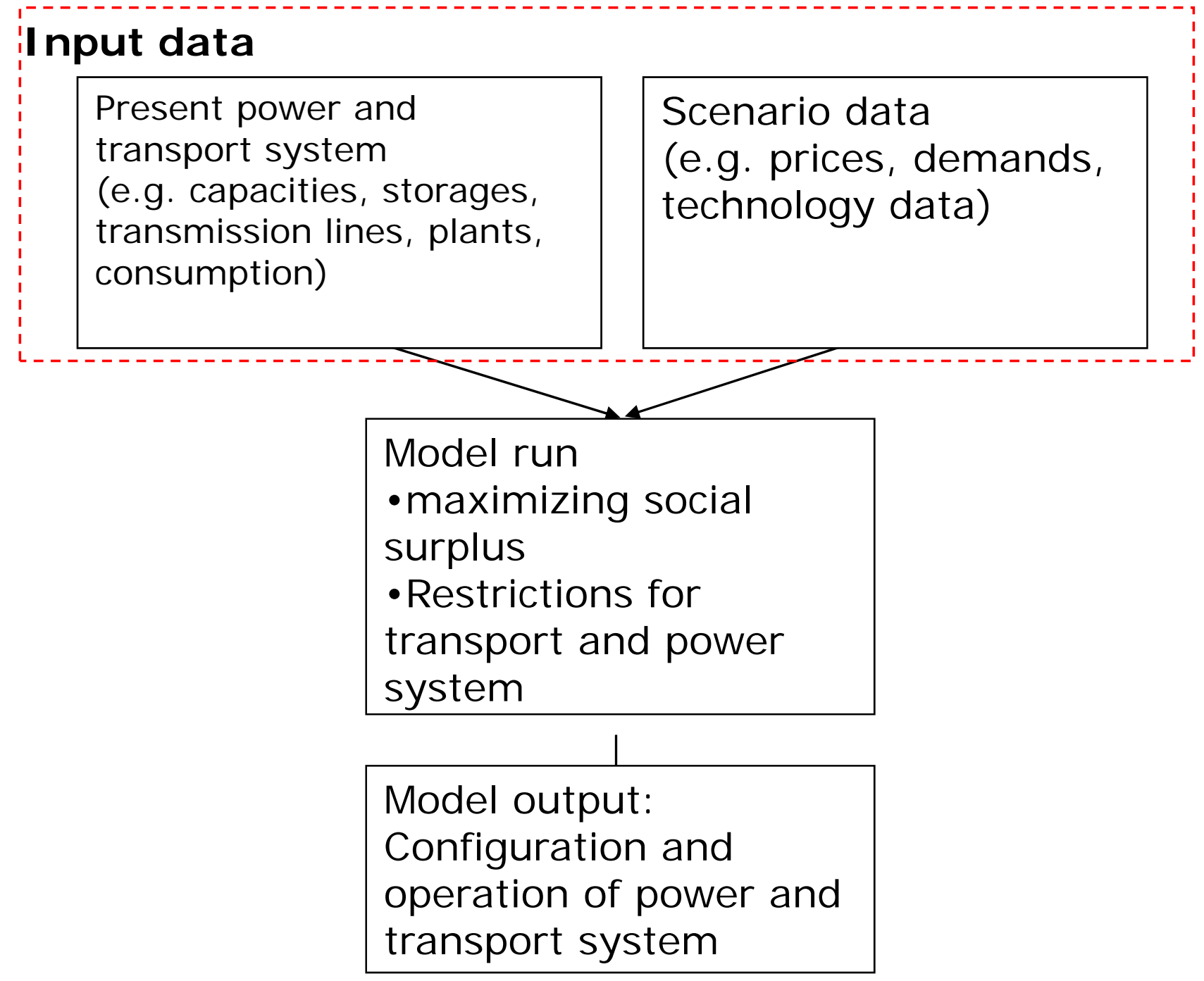




\section{Power flow}

- Power flow model of electric drive vehicles

a)

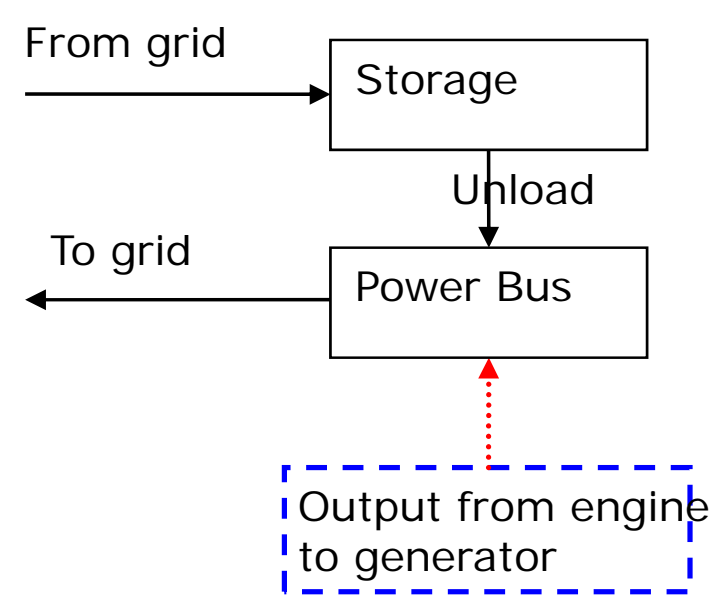

b)

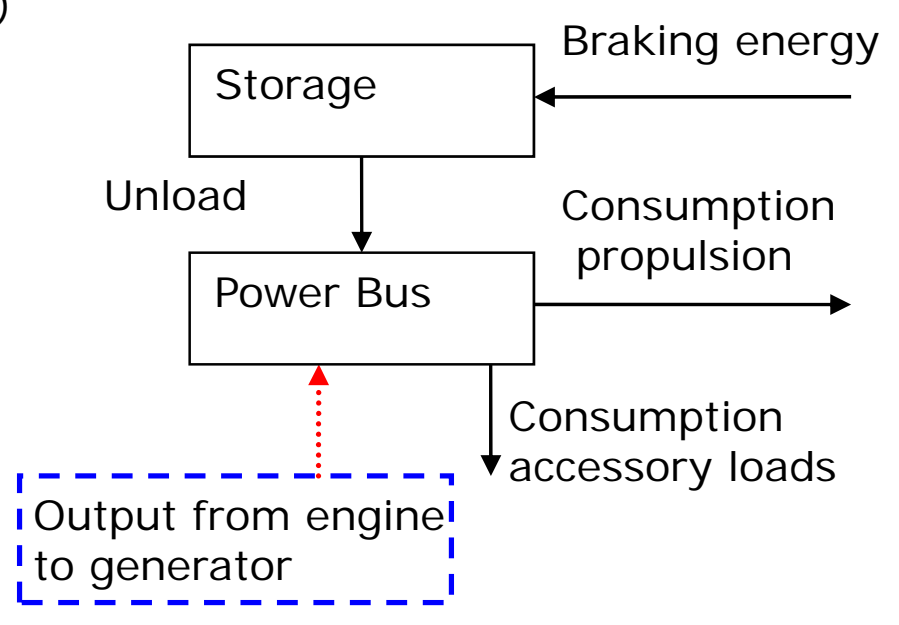

Applicable for PHEVs propulsion systems

- - -Replaced with output from fuel cell for FCEVs

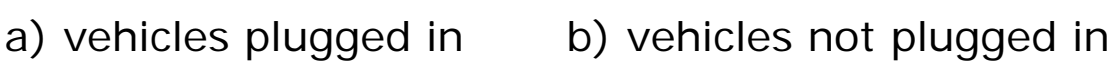




\section{Model formulation}

- Objective function: investments in vehicles

- Vehicle restrictions: balancing of on board storage (plugged in) balancing of the power bus (plugged in) transport supply and demand must meet minimum and maximum capacities

- Electricity balance equation: power to grid - power from grid 


\section{Assumptions}

- Communication system in place

- Vehicles are aggregated in vehicle groups

- Average driving patterns (forcing specific patterns for use of diesel)

- All vehicles leave grid with full storage

- Energy consumption of accessory loads and propulsion power proportional to vehicle kilometre driven

- PHEVs and FCEVs are assumed to use the electric motor until storage is depleted 


\section{Case description}

- Denmark, Finland, Germany, Norway and Sweden with transmission possibilities among these countries

- 7 selected weeks with hourly resolution ( 7 X 168 time steps)

- Year 2030

- Oil prices $\$ 120 /$ barrel (base), \$90 (low), \$130 (high)

- Constant fossil fuel price elasticities to oil

- $\mathrm{CO}_{2}$ prices $40 € /$ ton (base), $10 € /$ ton (low), 50€/ton (high)

- Including ICE, BEV, PHEV for persons transport 


\section{Case description}

Vehicle technology investment options

\begin{tabular}{lccc}
\hline $\begin{array}{l}\text { Type of } \\
\text { vehicle }\end{array}$ & $\begin{array}{c}\text { Annualised inv } \\
\text { costs }(€)\end{array}$ & $\begin{array}{c}\text { O \& M costs } \\
(€ / \text { year })\end{array}$ & $\begin{array}{c}\text { Electric storage } \\
\text { cap. }(\mathrm{kWh})\end{array}$ \\
\hline ICE & 1,065 & 1,168 & 0.8 \\
BEV & 1,513 & 1,101 & 50 \\
PHEV & 1,484 & 1,168 & 10 \\
FCEV & 1,893 & 1,101 & 10 \\
\hline
\end{tabular}

Medium and high wind targets (MW)

\begin{tabular}{lrrrrr}
\hline Wind target & Denmark & \multicolumn{1}{c}{ Sweden } & \multicolumn{1}{c}{ Norway } & \multicolumn{1}{c}{ Finland } & Germany \\
\hline Medium & 7,291 & 10,000 & 5,980 & 3,200 & 54,244 \\
High & 8,020 & 17,000 & 11,970 & 6,000 & 63,587 \\
\hline
\end{tabular}




\section{Case description}

- Investment options in power system:

- Onshore wind

- Offshore wind

- CHP plant biomass

- Open cycle gas turbine

- Heat storage

- Solid oxide electrolysis

- Heat pump

- Electric boiler

- Combined cycle natural gas

- Hydrogen storage, cavern 


\section{Results}

- Vehicles investments:

- ICEs in low oil scenarios

- PHEVs in all other scenarios 


\section{Charging of EVs distributed on hours during the day}

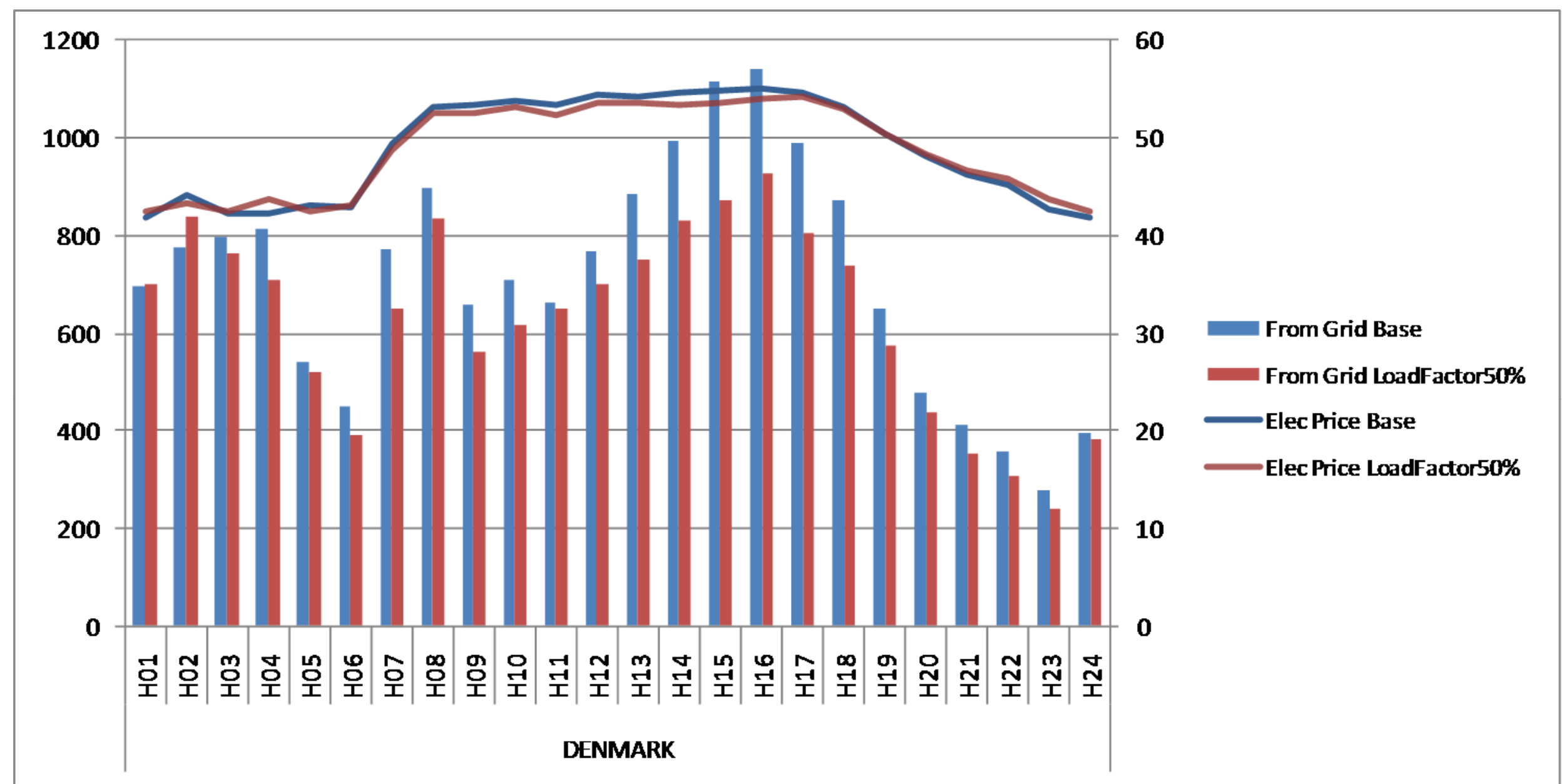




\section{Denmark: Yearly electricity production on fuel type}
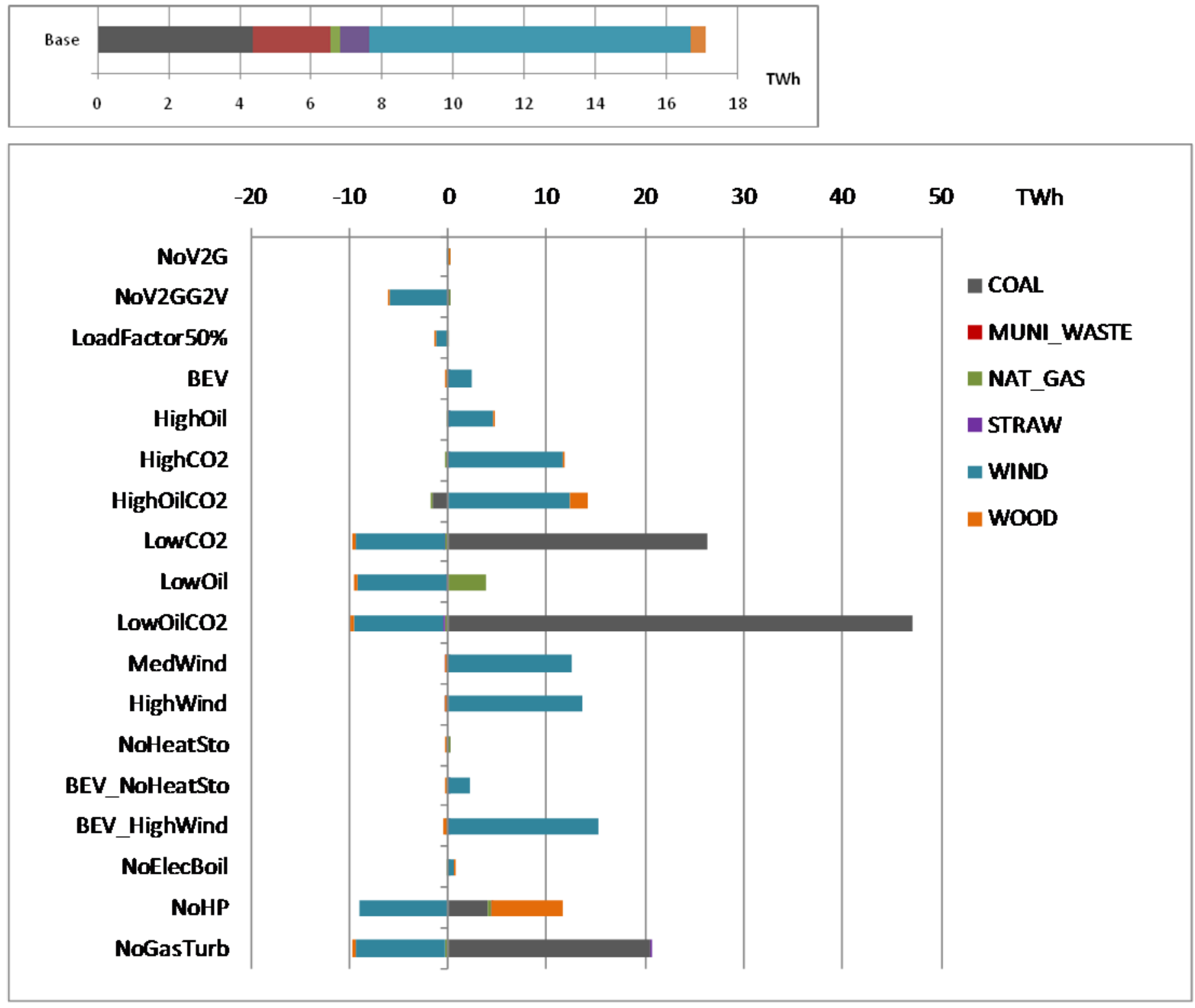


\section{Germany: Yearly electricity production on fuel type}
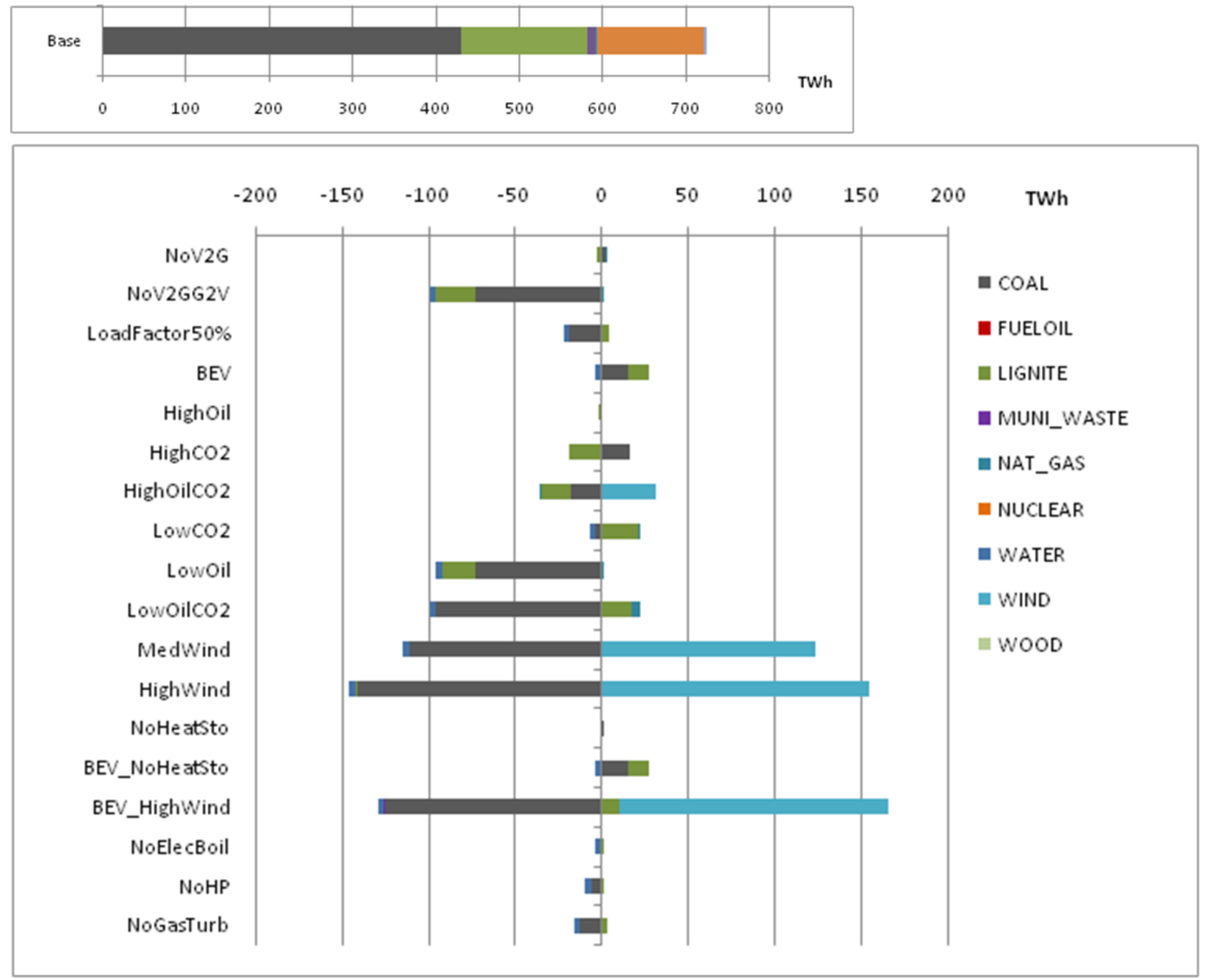


\section{Conclusions}

- PHEVs are very competitive across many scenarios compared to ICEs and BEVs

- Co-optimisation of vehicle and power system investments yields interesting results

- More work needed on requirement to leave the grid with full batteries

- Sustainability of EVs depend on development in surrounding power system:

- EVs drive on wind power in DK and on coal and lignite in D

- BUT: CO2 emission market might handle that issue 